\title{
The Community House (Dom Ludowy) in Nałęczów as an example of social architecture of the early $20^{\text {th }}$ century
}

\author{
Kamila Lucyna Boguszewska \\ https://orcid.org/0000-0002-1513-2490 \\ k.boguszewska@pollub.pl \\ Department of Modern Architecture, Faculty of Civil Engineering \\ and Architecture, Lublin University of Technology
}

\begin{abstract}
One of the most interesting facilities which were supposed to improve the quality of education of the poorest social strata were community houses. The popularity of this kind of institutions, dating back to the end of the $19^{\text {th }}$ century and the first half of the $20^{\text {th }}$ century, resulted in the construction of the Community House in Nałęczów, which, based on best practices, was to be a model of the realisation of a new, progressive society. The article presents the principles and "rules" for establishing such facilities by local communities in the context of activities undertaken in the difficult social and political situation of the areas under Russian rule. The history, operating principles, and architecture of the Community House in Nałęczów, which is an example of an out-of-the-box facility maintained in the national style, were herein analysed.
\end{abstract}

Keywords: Community House, Nałęczów, the national style

\section{Introduction}

The architecture of the public institution buildings in Nałęczów is unique in the whole area of the Lublin Governorate. One can risk a statement that in a sense, it is an undiscovered architecture, which only in the overall comparison illustrates the architectonic idea of the designers.

Public buildings in Nałęczów were erected with respect to the history and traditions of the health resort and its surroundings. Despite the prevailing fashions, architects and builders managed to achieve a unique style and character by transferring the patterns of national architecture to the area of Nałęczów without losing its regional features. The buildings erected in Nałęczów stand out from the historical villa and industrial architecture not only in terms of materials, but also in terms of architectural form rarely found in other parts of the country. It is noteworthy that the context of the place is respected and that it is very well connected with the surroundings and the undulating topography of the town. The architectural form and the functional solutions applied were connected with the activity of outstanding designers led by the architect Jan Witkiewicz Koszczyc, as well as the awareness of their patrons and founders. Being a health resort, Nałęczów became a recreation place for remarkable people from the world of science and literature who were close to the socialist stamina ${ }^{1}$.

The common denominator of the public buildings erected in Nałęczów between 1905 and 1914 was the fact that all of them were financed by the community of residents, various types of contributions, publishers, donations from societies and associations ${ }^{2}$, and the intelligentsia represented by the landowners, among others: Stanisław Śliwiński, Maria Kleniewska, the financiers: Karol Gottlieb Bloch, the doctors: Karol Benni, Wacław 
Lasocki, E. Kuńczyński, Bronisław Malewski, Kazimierz Chełchowski, the writers: Stefan Żeromski, Bolesław Prus. For these people, the positivist work at the grass roots was not unknown, they saw the future of resurgent Poland in the education of the lowest social strata. Often projects, prepared and supervised by outstanding architects, were made pro publico bono. The best example of this was the building of Ochronka (an orphanage) designed by Jan Witkiewicz Koszczyc or the School of the Association for the Support of Folk Industry (Szkoła Towarzystwa Popierania Przemysłu Ludowego) of the same architect.

One of the particularly interesting facilities which were intended to improve the quality of education of the poorest social strata was a community house. They were particularly popular at the end of the $19^{\text {th }}$ century and the first half of the $20^{\text {th }}$ century and were reflected in the construction of the Community House (Dom Ludowy) in Nałęczów, which, based on best practices, was to be a model of realisation of a new - progressive society.

\section{The state of research}

Currently, there is no monograph on the subject of architecture of community houses built in the Lublin Voivodeship in the early $20^{\text {th }}$ century. However, the popularity of these buildings in the Lublin Governorate has resulted in the publication of numerous books providing instructions on how to establish, finance and operate such public buildings. Noteworthy are the publications of Kazimiera Bujwidowa (1903) ${ }^{3}$, Stanisław Posner (1907) ${ }^{4}$, Wacław Budzyński $(1918)^{5}$, Wanda Kosmowska $(1918)^{6}$, Ignacy Gliksman $(1923)^{7}$, Wojciech Sosiński (1925) ${ }^{8}$, Alex Kurcyjusz (1927) ${ }^{9}$, as well as model statutes of Society of Community Houses (Towarzystwo Domów Ludowych) describing the principles of organising this type of facilities and examples of good practice. In addition, due to the growing popularity of the Community Houses, in the 1930s, actions of building workers' houses were organised, an example of which was the realisations in the oil basin. The effects of these works were published in numerous books and brochures. [Fig. 1]

\section{The functioning of "the model community house"}

At the beginning of the $20^{\text {th }}$ century, the development of "social life and cultural work of a village, settlement or town" was closely linked to the institution of a Community House, which was the seat of local societies, machinery rings, and savings and loan associations. This building, financed by the inhabitants, was an important place of cultural and educational life of a village ${ }^{10}$.

Their architecture was diverse. Initially, it derived from the style of national architecture (manor house), later, with the development of the workers' movement, it was maintained in the modernist style and in its initial phase - functionalism. [Fig. 3A, B, C, Fig. 2]

The fashion for building Community Houses has covered the entire territory of the former Congress Poland. In the Lublin region, there were many such objects, most of which date back to the first half of the $20^{\text {th }}$ century. The particular popularity of this function is evidenced by the number of projects commissioned by different local governments, e.g. in Lubartów (1928, 1936), Łuków (1923), Golice (1936-1937), Czółno (1929), Sitaniec (1922), Józefów (1925), Warszawice (1925), Kryłów (1939), Drelów (1939), Olszanka (1927), Dziarkowice (1939), Korczew Podlaski (1924), Ksawerówka (1928), Kraśnik (1938), Urzędów (1938), Teptiuków (1939), Tłuść (1936), in the village of Dąbie (1927), in Krężnica Jara (1927), Konstantynów 1927, Milanów 1927, Krasnystaw

3 K. Bujwidowa, Domy ludowe, Wydawnictwo Krytyka, Kraków 1903.

4 S. Posner, Domy Ludowe w Belgii, Wydawnictwo Krytyka, Kraków, 1907.

5 W. Budzyński, Pogadanki wzorowe znaczenie domów ludowych, Wydawnictwo Szkółek Rolniczych C.T.R. w Królestwie Polskim, 1918.

W. Kosmowska, Towarzystwo szkoły ludowej w Galicji z cyklu drogi do oświaty, Wydawnictwo M. Arcta w Warszawie, 1918.

I. Gliksman, Domy ludowe ich organizacja i znaczenie dla rozwoju kultury narodowej, Warszawa 1923.

8 W. Sosiński, Jak zakładać dom ludowy i prowadzić towarzystwo domu ludowego wskazówki organizacyjne, Centralny Związek Kółek Rolniczych, Komisja Domów Ludowych, Warszawa 1925.

9 A. Kurcjusz, Znaczenie Domów Ludowych w Polsce w dobie obecnej, Warszawa 1927.

10 W. Sosiński, Jak zakładać dom ludowy i prowadzić Towarzystwo Domu Ludowego, wskazówki organizacyjne, warszawa 1925, (Warszawa: Druk. Art. K. Kopytowski), p. 6. 
1938-1939, Łopienniki Dolne 1927, Tomaszów Lubelski 1924, Wola Rawska 1938, Baranów n/ Wieprzem 1939, Tomaszów Lubelski 1931, in the village of Kulno 1923, in Groszki Stare 1933, in the village of Chojeczno 1934, Janów Lubelski (1924 - reconstruction), in Biała Podlaska $1937^{11}$.

\section{"Principles" for establishing a Community House}

According to the general postulations, a Community House was to fulfil a number of functions, among the others: it was to be "the most active centre of the improved economic life of the area", especially "in the field of agriculture, rural industry, trade, all associations and unions ${ }^{\prime \prime 2}$.

An important function performed by such buildings was also the educational function: "Community houses organise readings and lectures everywhere (...) which are the basis of education ${ }^{\prime \prime 3}$. What is more, they were also a place for integrating the community - "intelligence comes closer to the people" and were centres of cultural and social life $e^{14}$.
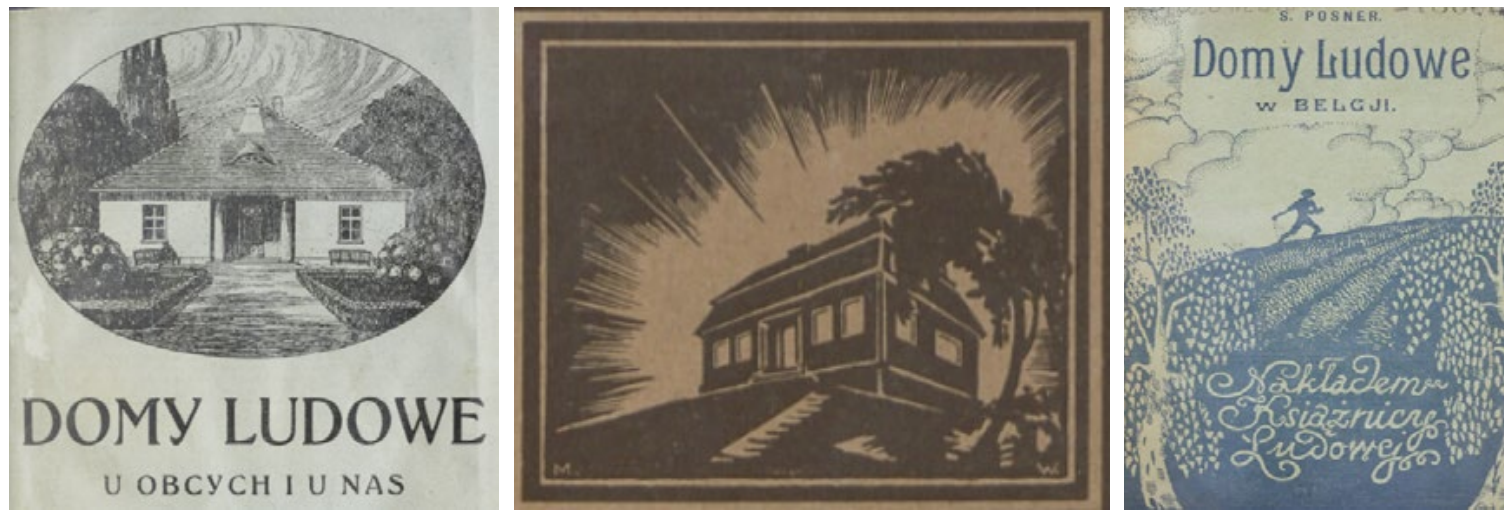

Fig. 1. Covers of publications concerning the principles of establishing and functioning of Community Houses
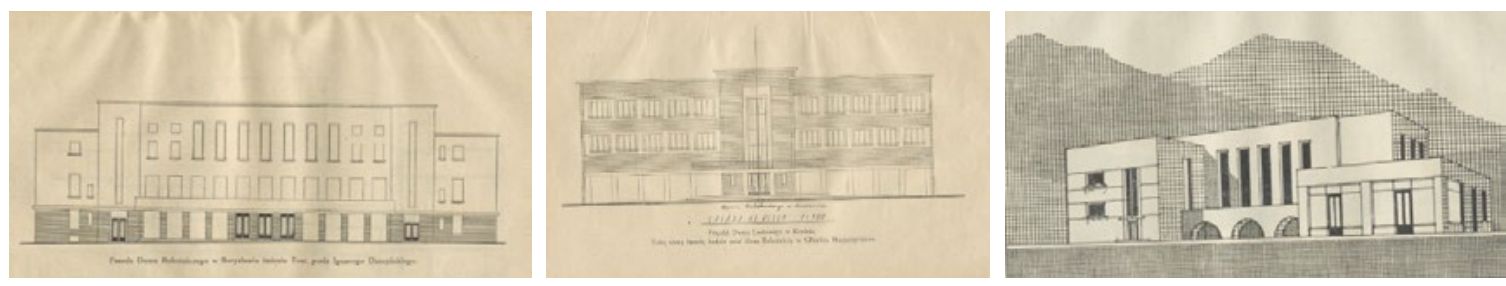

Fig. 2. Modernist Community Houses of the Oil Basin.

The location of this type of facility was strictly defined. According to a number of guidelines promoted in the press and literature for the establishment of the model Community Houses, a building fulfilling this function should meet the "educational, social and cultural" needs of a local community. Its location should allow for the possibility of expanding and providing space for sports equipment - in the form of sport fields and fitness facilities. The plot should be located in the centre of the village and give an opportunity to expand the building in the future. 

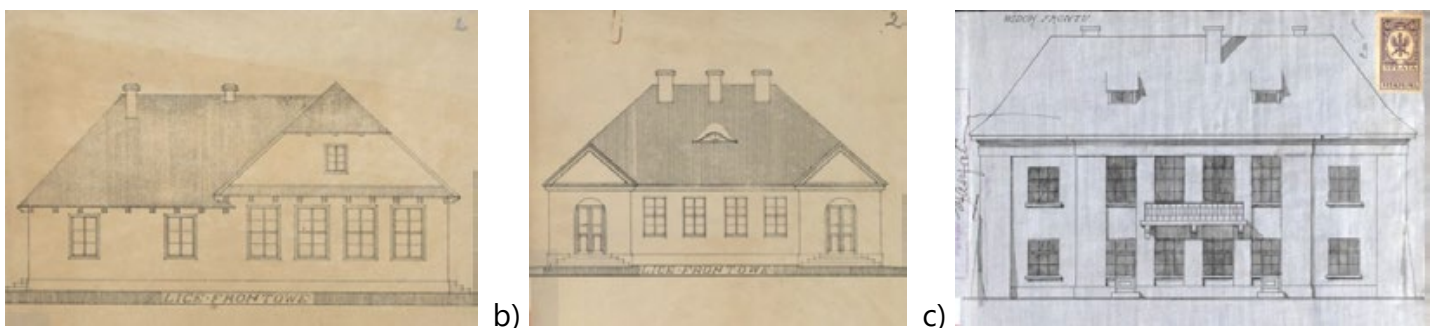

Fig. 3. A The design of the community house in the village of Dąbie (1927), p. $1251 \mathrm{APL}, \mathrm{B}$ in the village of Olszanka (1927), p. 1294, APL, C. in Józefów, p. 487 (1925) APL

a)
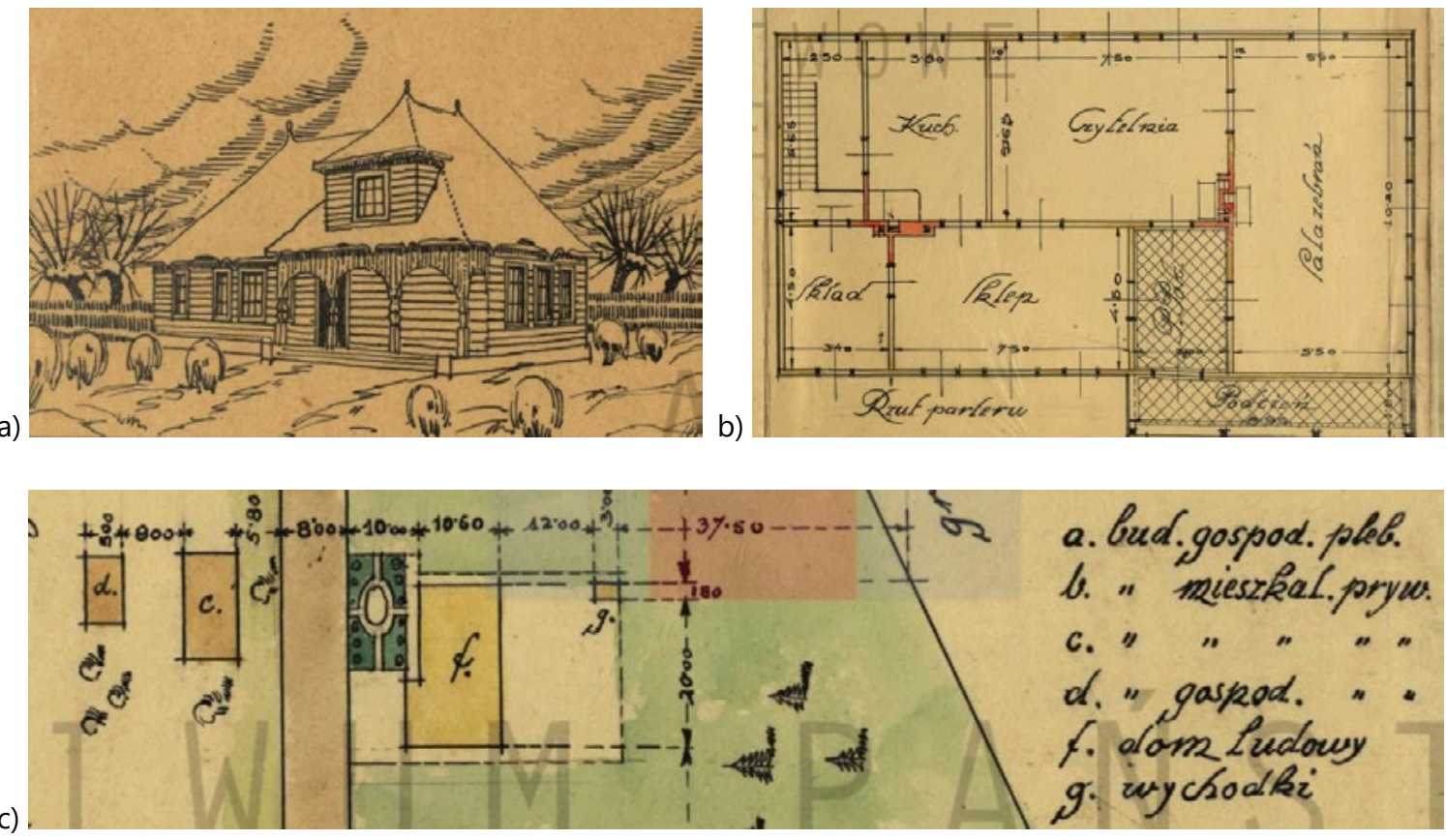

Fig. 4. The design of the community house in Krężnica Jara, Lublin powiat, 1926, p. 1666, APL, A - a perspective view, B - plan, $\mathrm{C}$ - development of the plot

In bigger municipalities, the Community Houses were situated in parks and gardens, in smaller, it was recommended to place the building by the road with a buffer of insulating greenery. [Fig. 4C] In terms of the functional programme, the Community Houses were to fulfil educational and cultural functions:

a meeting room for readings, theatre performances and fitness for about 200 people in smaller and 300-400 people in larger towns,

- a reading room together with a library that must be fully illuminated,

- a local museum in the form of a regional chamber presenting "historical memorabilia, excavations, specimens of folk art and local works, natural specimens (...) plans of model buildings"15,

a common room - a club,

- rooms serving as offices of unions and institutions, (guest rooms),

- guard's lodgings. [Fig. 4A, B]

It was recommended to locate a grocery shop, municipal office or fire brigade as an additional function of a Community House building. [Fig. 5 A, B, C] According to the guidelines and recommendations, the design of the building should be prepared by a person with appropriate qualifications. The building should be "the most 
beautiful in the village, a testimony of the power of collaboration and a model of construction". It was recommended to entrust these designs to architects - "those who are specially dedicated to this type of construction (preferably with the Community Houses Commission").

The design, together with the cost estimate of the Community House building, was subject to approval by the state office - the district architect or the District Directorate of the Public Works. The local community having the design and cost estimate could apply for a state loan ${ }^{16}$.

a)

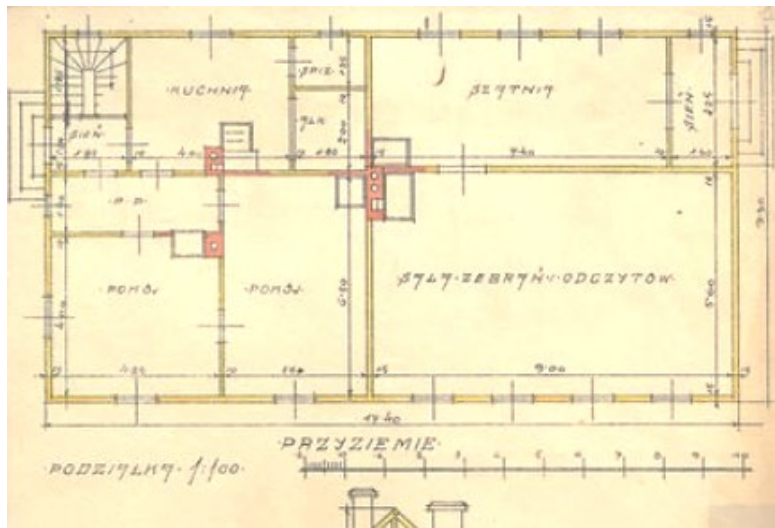

b)

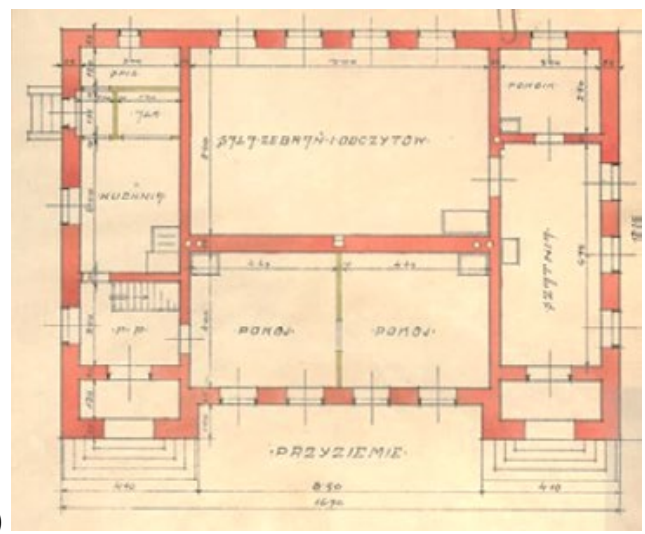

c)
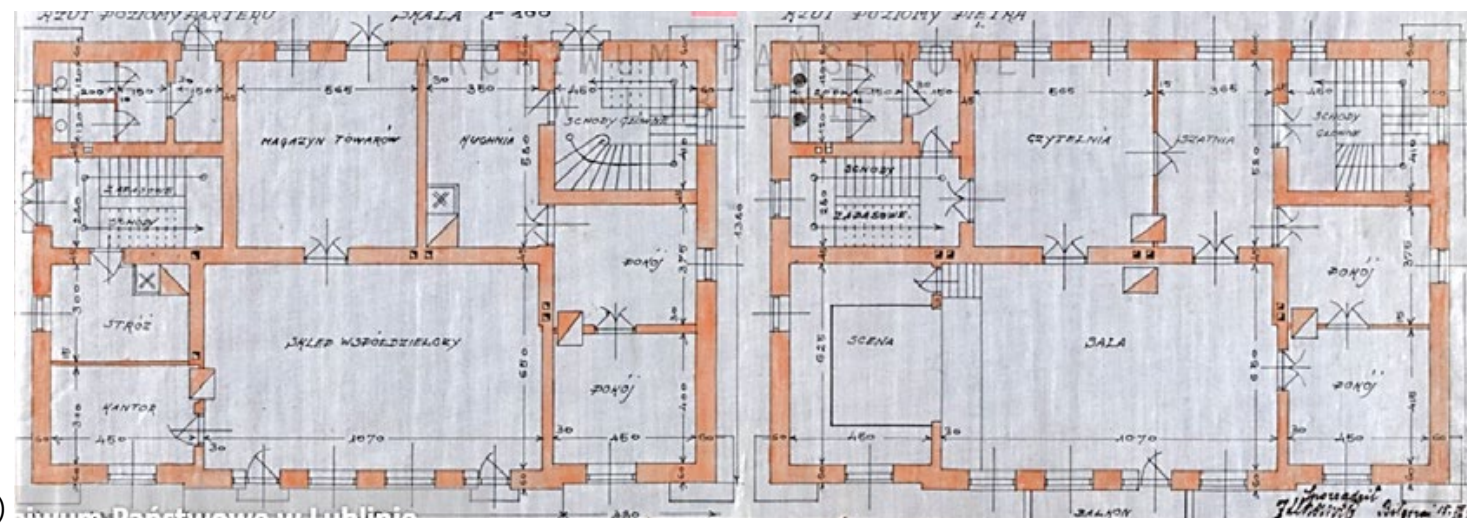

Fig. 5. A - The design of the community house in the village of Dąbie (1927), p. 1251 APL, B - in the village of Olszanka (1927), p. 1294, APL, C - in Józefów, p. 487 ( 1925) APL

\section{The Community House in Nałęczów}

The construction of the Community House building in Nałęczów is connected with the activity of Stanisław Śliwiński, a landowner and patriot, bringing together a group of local landowners who he was teaching "(...) not only to improve the farming, but also to feel and understand the civic mission in the national spirit ${ }^{17 "}$.

The beginning of the $20^{\text {th }}$ century, and especially the year 1905 , brought an intensification of cultural, educational and social activities in the Lublin Governorate. The willingness to oppose the Russification through professional education (elementary schools, educational and cultural institutions) was reflected in numerous emerging machinery rings and associations. These activities undertaken due to "positivist" ideas became possible in Nałęczów thanks to a group of enlightened people ${ }^{18}$ who belonged to the Nałęczów Credit Society 
(Nałęczowskie Towarzystwo Kredytowe) (1903) and who were also residents of the resort. In 1906, a machinery ring was established in Nałęczów, which was a superior body to the existing agricultural enterprise "Zgoda" and the Nałęczów Credit Society. The person who was mainly responsible for the management of the ring and its spiritus movens was Stanisław Śliwiński - the initiator of the construction of the community house in the Nałęczów health resort ${ }^{19}$.

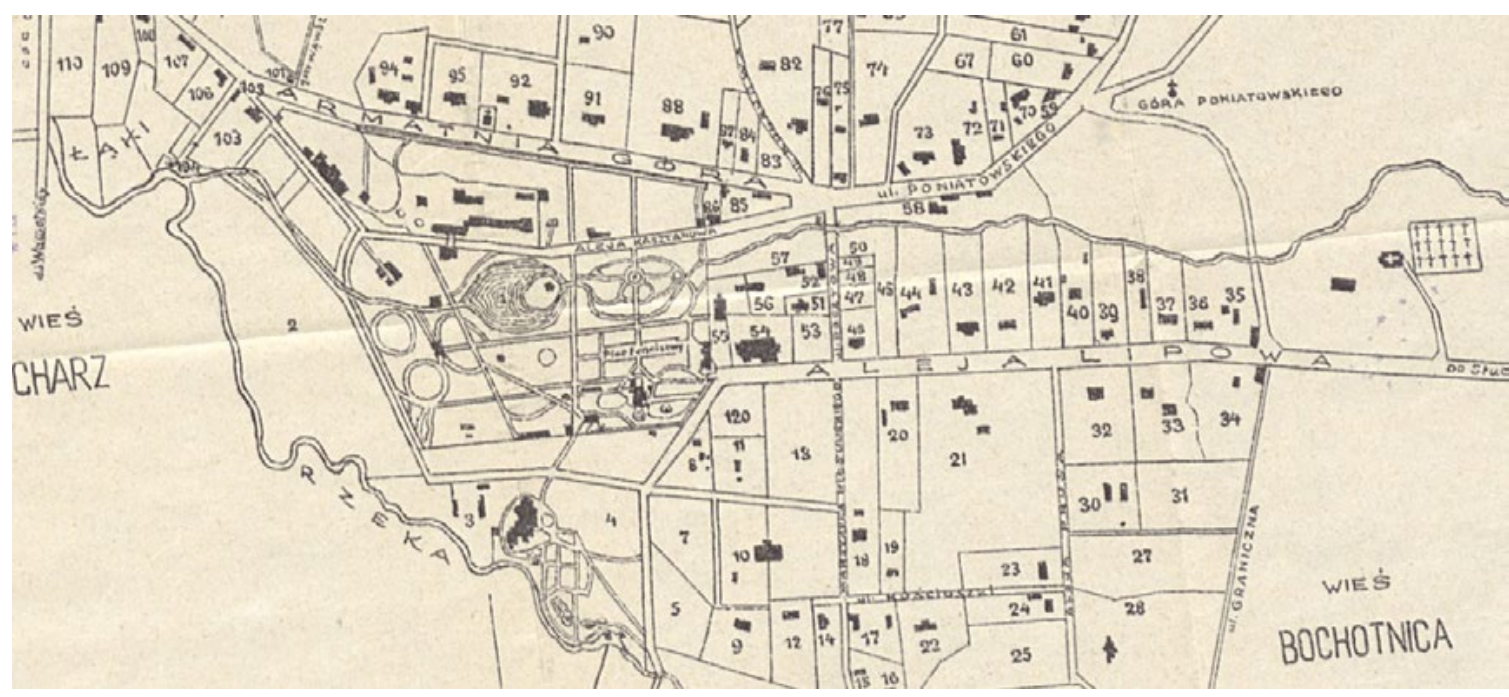

Fig. 6. A part of Nałęczów Situation Plan from 1934, the location of The Community House

The Community House "Ludowiec" in Nałęczów was fulfilling the above-mentioned functions. From the very beginning, it was the seat of a school, with classes taking place in two lecture halls on the first floor, ${ }^{20}$. Apart from that, the building also hosted numerous associations. In the basement there was a guardian's flat and a tea room ${ }^{21} 22$, on the ground floor there was so-called "cash register" - Nałęczów Credit Society and on the first floor there was a Machinery Ring (transformed in 1909 into the District Agricultural Society of Nałęczów ${ }^{23}$ ). [Fig. 6]

Two years later, the collections of the Lublin Land Museum (Muzeum Ziemi Lubelskiej founded in 1904 by Dr. Lasocki, Malewski and Puławski) were moved to the Community House ${ }^{24}$.

The Lublin Land Museum was later called the Nałęczów Museum (Muzeum Nałęczowskie). The collections included folk costumes from the Lublin Governorate, models of cottages and manor houses, as well as various species of birds, engravings and drawings collected by Dr W. Lasocki ${ }^{25}$. Apart from that, on the ground floor of the Community House, there was a shop which was opened on 1 February 1908. The Community House was the seat of the Cooperative "Oszczędność" 26 .

19 A. Przegaliński, W kręgu Stanisława Śliwińskiego i nałęczowskiej oświaty rolniczej na przełomie XIX i XX wieku, Rocznik Lubelski 35, 2009, p. $140-143$.

20 A. Elaszuk, Czego nas uczono i jak żyliśmy w Szkole Rolniczej w Nałęczowie, Odczyt sprawozdawczy na ogólnem zebraniu Włodawskiego towarzystwa Rolniczego w Sosnowicy, Warszawa p. 7.

21 The community teahouse was located in a basement with beautiful arched vaults and walls of unplastered red brick. It functioned for a year and a half. Later, in 1909, it was replaced by a café run by Ms. Wisłockas. During the First World War it was reopened by Aleksander Gustaw Malawski, then Mrs. Neyman. In 1916 a reading room was opened in the tearoom. Eventually the reading room together with the tearoom was closed in 1918. After: J. Babinicz Witucka, Krótka historia nałęczowskiej herbaciarni, Głos Nałęczowa, Towarzystwo Przyjaciół Nałęczowa, p. 18-19.

22 Throughout the entire period of World War I, the Community House was housing a tearoom run by Aleksander Gustaw Malewski, who was president of the Citizens' Committee. During the war, it was called "czajnia". Due to financial problems connected with its maintenance, it was closed on $15^{\text {th }}$ May 1918. After: J. Babinicz Witucka, Nałęczów w czasie I wojny światowe wybrane wydarzenia, in: Pamięć wielkiej wojny, p. 9.

23 A. Przegaliński, W kręgu Stanisława Śliwińskiego i natęczowskiej oświaty rolniczej na przełomie XIX i XX wieku, Rocznik Lubelski 35, 2009, p. 143.

24 Originally, they were stored in the Malachowski Palace under the care of Dr. B. Malawski, and later W. Lasocki.

25 I. Iskrzycka, Z dziejów Towarzystwa pod nazwa "Muzeum Lubelskie", studia i Materiały Lubelskie, 1968, vol. 8, p. 24, after: Lublinianin of 16.09.1907, no. 58.

26 A. Przegaliński, W kręgu Stanisława..., op. Cit., p. 143-149. 
During World War I, a camp office was established in the dormitory ${ }^{27}$ of an agricultural school in the Community House. Its role was to find accommodation for the population ${ }^{28}$. In the interwar period this building was not used much ${ }^{29}$. The guides from the 1920s say: The Community House was built on the initiative of Wactaw Lasocki. It housed the ethnographic and natural history museum of the Lublin Land founded by him and later donated to the Lublin Land Museum. Currently, the Community House houses the men's agricultural school. The Community House does not meet its purpose here, as it does not have a theatre hall or a place to play or to meet, and yet Natęczów misses it much ${ }^{30}$. After the war, the Community House was home to shops and warehouses. On the ground floor for nearly twenty years there was a photographic studio of Małachowski and on the first floor the seat of the Catholic Action which was adapted by the Roman-Catholic parish. There is also a café here to this day. The rest of the rooms are not used.

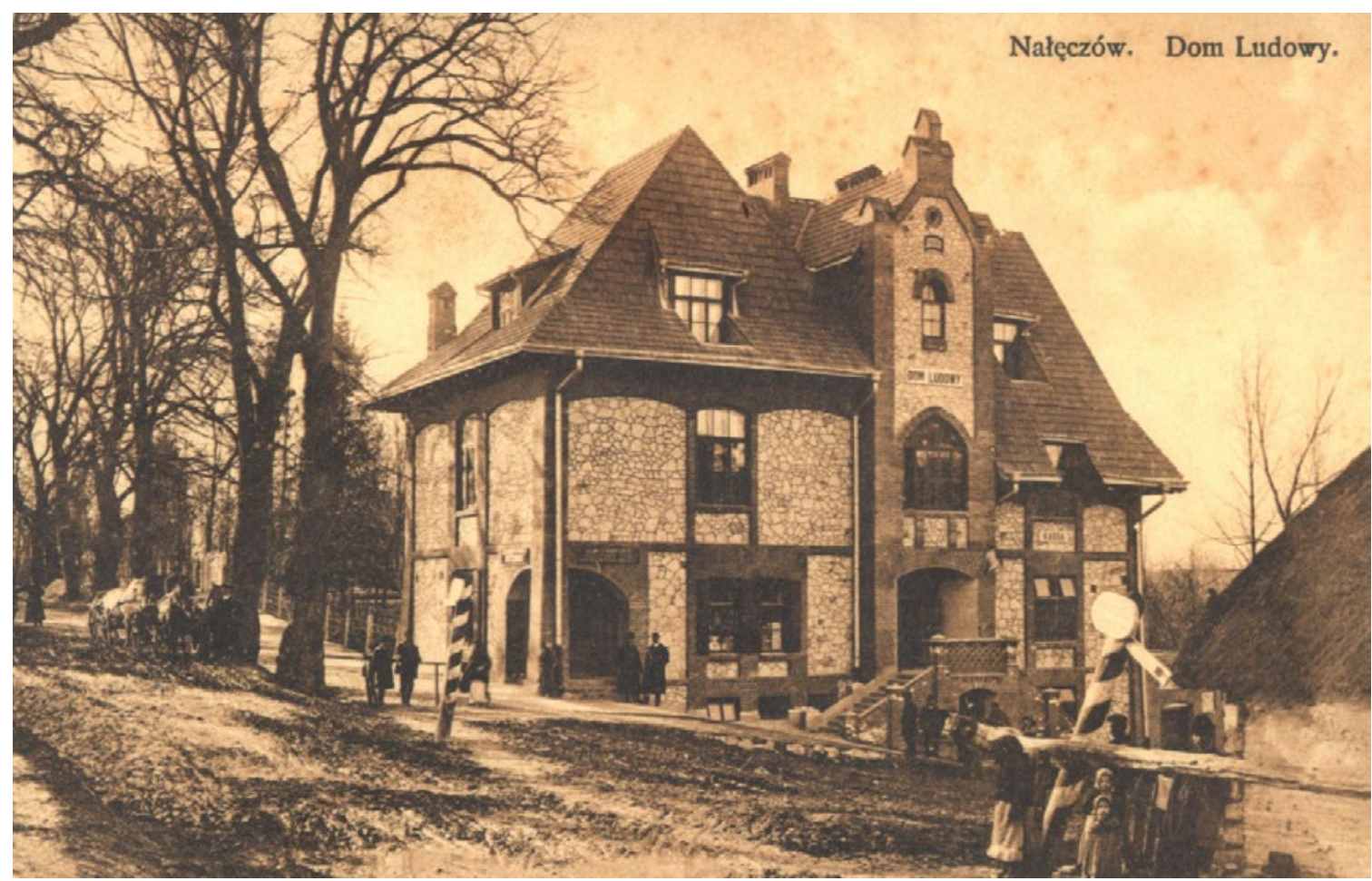

Fig. 7. "Dom Ludowy" in Nałęczów, 1912, Archive Teatr NN

\section{Six-month winter courses for landowners in Nałęczów}

One of the main functions for which the Community House was built were winter courses for landowners intended for men under 16 years of age and able to read, with priority given to men from the Lublin Governorate. The schooling initially lasted six months and was later reduced to five months. Its cost was between 40 and

27 Most of the students lived in private accommodation paid for by the course management, but there were six small rooms available. After: A. Przegaliński, W kręgu Stanisława..., op. cit., p. 150.

28 J. Babinicz Witucka, Nałęczów w czasie I wojny światowe wybrane wydarzenia, in: Pamięć wielkiej wojny, p. 9.

29 The Community House in Natęczów is completely different in its character. It stands alone and deaf most of the year. Although there are 6-month agricultural courses held there, but then no one gives general lectures, people do not gather there for meetings and hearings, they do not take possession of it. This is a great pity, not only because the facility, which is so rare in our region, is not sufficiently exploited, but also because of its exceptional supply of scientific aids, which should be made as widely available as possible. after: W. Kosmowska, Domy ludowe $u$..., op. cit., p. 85-86.

30 Nałęczów, Zdrojowisko i letnisko sezon 1928-1929, jednodniówka pod redakcją Feliksa Petrucznika, Wydawnictwo Komisji Zdrojowej w Nałęczowie, p. 48 
50 rubles. The course was managed by a committee appointed every year from the Lublin Agricultural Society and approved by the Lublin governor. The lectures, similarly to the nearby School of Women Landowners, were given in Polish. The programme included subjects such as botany, zoology, agricultural science, horticulture, breeding, gardening, beekeeping, dairy, veterinary, hygiene, land measurement, arithmetic and physics ${ }^{31}$. A former student of the school A. Elaszuk wrote extensively about the curriculum. The theoretical classes were accompanied by practical classes conducted already from March, among others "practical work in the garden and nurseries in Antopol" and excursions to nearby estates, the aim of which was to consolidate the acquired knowledge, among others in the estates in Rumblów, Czesławice or Antopol. The schooling ended with an exam and a certificate of completion of agricultural courses ${ }^{32}$.

a)

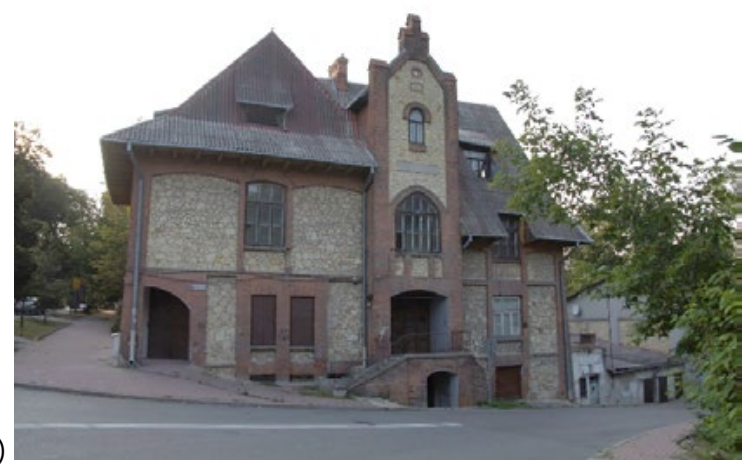

Fig. 8. A - The Community House, the author's on photograph, 2018, "B The Community House in Nałęczów, 2018, the author's on photograph, B schematic plan of "the Community House" the author's archive.
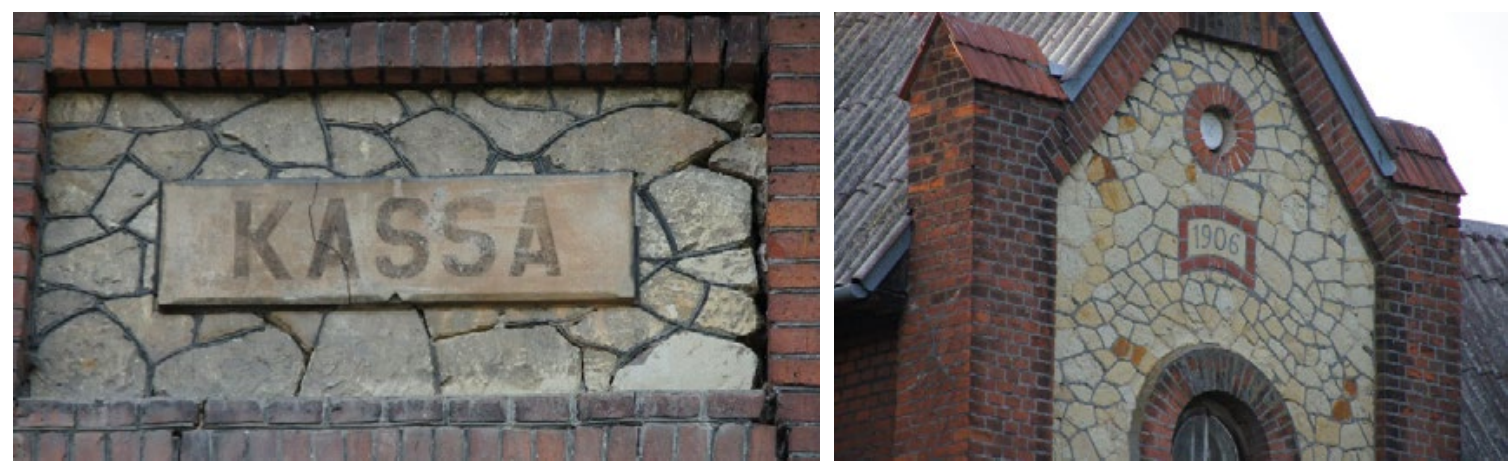

Fig. 9. The Community House, architectural details, author's own photograph, 2018

31 A. Przegaliński, W kręgu Stanisława Śliwińskiego i natęczowskiej oświaty rolniczej na przełomie XIX i XX wieku, Rocznik Lubelski (Lublin yearbook) 35, 2009, p. 149-150.

32 A. Elaszuk, Czego nas uczono i jak żyliśmy w Szkole Rolniczej w Nałęczowie, Odczyt sprawozdawczy na ogólnem zebraniu Włodawskiego towarzystwa Rolniczego w Sosnowicy (report), Warszawa p. 19-21. 


\section{The architecture of the Community House in Nałęczów}

The architectural form of the Community House building referred to the national style ${ }^{33,34}$. The regional character was emphasized by the construction materials $\mathrm{s}^{35}$ used, in the form of limestone and brick, which created a characteristic detail in the form of frame division on the facade. It was later repeated in the architecture of the outbuilding added to the building from the side of Graniczna Street.

The "Ludowiec" building, as it was commonly called, was built in 1906 according to the design of Warsaw architect Zenon Chrzanowski ${ }^{36}$. The plot of land on which the building was erected had an area of 1482 square ells and was purchased for 50 rubles from Józef F. Bagieński. Due to the law prevailing in the Kingdom of Poland, the parcel intended for the construction of the Community House could not belong to one person ${ }^{37}$. The construction works and related costs were paid in full by the Nałęczów Credit Society headed by Stanisław Śliwiński and the contributions of the Nałęczów inhabitants and the local community ${ }^{38}$.

The building has been given a two-storey body covered with a hipped roof with numerous dormers and a three-tiered roof of the risalit of the front façade. Originally, the roof of "Ludowiec" was covered with wooden shingles - now with eternit. The front façade (from the side of Graniczna Street) was emphasised with a single-axis risalit enclosed in brick pilasters and finished with a trapezoidal gable with a crenellation. The building has a protruding eaves ${ }^{39}$ and an arcade at the corner at the intersection of Lipowa and Graniczna Streets. [Fig. 7, 8A] In the past this was the place where the shop used to operate.

"Ludowiec" was accompanied by an outbuilding erected between 1906 and 1909 and connected to the building with the use of a connector. From the beginning of its existence the building was supervised by the Cooperative "Oszczędność". Similarly to "Ludowiec", it was erected of limestone and brick, from which pilasters, cornices and window frames were made. A characteristic frame division also appeared on the façades. [Fig. 9] The building served as a warehouse, butcher's shop and sewing room. At the beginning of the $20^{\text {th }}$ century, it was partly adapted for the flat and furniture maintenance workshops. It also functioned as a storage facility ${ }^{40}$. [Fig. 8B]

33 The architecture of the Community House building was arousing mixed feelings among the residents of Nałeczów. According to W. Kosmowska, it was a beautiful building with aesthetic lines, preserving the style of the so-called Vistula - Baltic style, showing the artistic aspirations of its creator, who left his mark on all buildings constructed for social institutions in Natęczów. (...) A similar opinion was also held by one of the students of the agricultural course, A. Elaszuk, who described the popular "Community House" as a beautiful building. Lucia Hornowska, who wrote in her memoirs: "On the corner of Lipowa Avenue (Graniczna Avenue) in front of the church, a heavy, clumsy red-brick bunker was built, the "Community House". After: W. Kosmowska, Domy ludowe u obcych i u nas, Warszawa; Lublin : Wydawnictwo M. Arcta, 1918 (Warszawa : Druk. M. Arcta), p. 85-86, . A. Elaszuk, Czego nas uczono i jak żyliśmy w Szkole Rolniczej w Nałęczowie, Odczyt sprawozdawczy na ogólnem zebraniu Włodawskiego towarzystwa Rolniczego w Sosnowicy, Warszawa p. 7, J. Babinicz Witucka, Krótka historia nałęczowskiej herbaciarni, Głos Nałęczowa magazine, Towarzystwo Przyjaciół Nałęczowa, p. 18.

34 The style of the Community House in Nałęczów is described by some researchers and regionalists as the Zakopane style. An even more intricate term, which proves the eclecticism of the architectural elements that have been used, was given by $Ł$. Heymann, who wrote that the architecture of the building is a composition in the spirit of processing anonymous, small-town medieval solutions (with motifs of the 'Zakopane style'), after: Ł. Heymann, Co i jak zbudowano w Natęczowie miedzy wojennym czyli dzień powszedni architektury ówczesnej, Między wschodem a zachodem część III kultura artystyczna pod redakcją Tadeusz Chrzanowskiego, Lublin 1992, Lubelskie Towarzystwo Naukowe, p. 450.

35 The materials used in "Ludowiec" were characteristic for most of the public buildings erected at the beginning of the $20^{\text {th }}$ century in Nałęczów (the School of Women Landowners, the Jan Bloch Toy Instructors' School, the Carving School, etc.)

36 The architect Chrzanowski Zenom was born in 1877 in Smotryszew and died in 1922. He completed the architecture in St. Petersburg and designed the parish in Jedlnia (1902-1903), the building of the Gen. P. Chrzanowski gymnasium (later J. Zamoyski gymnasium) in Warsaw and houses "for himself" in Piaseczno. After: S. Łoza, Architekci i budowniczowie w Polsce, Warszawa Budownictwo i Architektura, 1954, p. 47

37 The plot was owned by: Stanisław Śliwiński, Antoni Puławski, Bronisław Malewski and Wincenty Wójcicki. After: M. Tarka, Dzieje Nałęczowa Towarzystwo Przyjaciół Nałęczowa, 1989, p. 99.

38 lbid., p. 99

39 Karta WUOZ/Lublin, A. Sikora-Terlecka, Dom Ludowy, 1996, p. 4518.

40 Karta WUOZ/Lublin, A. Sikora-Terlecka, Dom Ludowy, 1996, p. 4518. 


\section{Summary}

The architecture of the Community House in Nałęczów stands out from other buildings built at the same time in the Lublin Governorate area. It is not without significance that the building was erected in the Nałęczów health resort, which were bringing together people of culture and science, who wanted to educate the poorest social strata, thus fulfilling the demands of positivist work at the grass roots.

The building has been maintained in the national style, as evidenced by its form, sloping roofs and dormers, which are a distant reminiscence of manor house architecture. However, architectural detail of the building that is unparalleled in the area of Nałęczów is remarkable. Through the variety of materials - brick, limestone and a detail in the form of pilasters, decorative gables, crenellation or characteristic frame division, the original building was obtained which is not a typical object promoted in numerous leaflets and instructions for establishing Community Houses. Certainly, it was the designer Zenon Chrzanowski who had the merit here, who tried to create a building that would fit in well with the landscape of the health resort and referred to the tradition of the place and local folk architecture. The use of the above mentioned materials became the norm for the construction of subsequent educational buildings. Therefore, one can risk a statement that the building of the Community House in Nałęczów initiated, in a way, this trend in the architecture of educational facilities of the Nałęczów region in the first half of the $20^{\text {th }}$ century.

Considering this building from a wider perspective in terms of its location and functional solutions and in the context of materials in the form of preserved archival records, it should be noted that the difficult plot of land on which the building was located (both in terms of shape, proximity of the road system and differences in relative height) constituted a huge potential on the other hand. Although it did not meet the requirements for the organisation of space in the form of sports infrastructure and insulating greenery, it provided full exposure of the southern and eastern façade - which is the front façade. The representative staircase highlighting the main entrance to the building and serving as a "compensating run" successfully accentuated the main risalit.

The Community House building became the first representative building (after the church) on the side of the Lublin-Nałęczów route. From the functional point of view, it should be noted that the Community House in Nałęczów was not large. It served as a school, savings bank and shop. However, it is true that the designer did not foresee a theatrical hall in the functional programme of the building, which was widely commented on by the then guests and residents of the resort.

To sum up, the Community House in Nałęczów is an example of aspiring architecture of the beginning of the $20^{\text {th }}$ century, which was part of the then ideological programme without losing the originality of the architecture itself.

\section{Literature}

[1] Archiwum Wojewódzkiego Konserwatora Zabytków w Lublinie, A. Sikora-Terlecka, Dom Ludowy, 1996, p. 4518.

[2] Babinicz Witucka J., Krótka historia nałęczowskiej herbaciarni, Głos Nałęczowa magazine, p. 18-19.

[3] Babinicz Witucka J., Nałęczów w czasie I wojny światowe wybrane wydarzenia, in: Pamięć wielkiej wojny, Budzyński W. Pogadanki wzorowe znaczenie domów ludowych, Wydawnictwo Szkółek Rolniczych C.T.R. w Królestwie Polskim, 1918.

[4] Budzyński W., Znaczenie domów ludowych, pogadanki wzorowe, Warszawa: Z.K.R., 1918 ([Warszawa]: Druk. "Gazety Rolniczej").

[5] Bujwidowa K., Domy ludowe, Wydawnictwo Krytyka, Kraków 1903.

[6] Elaszuk A., Czego nas uczono i jak żyliśmy w Szkole Rolniczej w Nałęczowie, Odczyt sprawozdawczy na ogólnem zebraniu Wtodawskiego towarzystwa Rolniczego w Sosnowicy, Warszawa p. 7.

[7] Gliksman I., Domy ludowe ich organizacja i znaczenie dla rozwoju kultury narodowej, Warszawa 1923.

[8] Heymann Ł., Co i jak zbudowano w Natęczowie miedzy wojennym czyli dzień powszedni architektury ówczesnej, Miedzy wschodem a zachodem część III kultura artystyczna pod redakcją Tadeusz Chrzanowskiego, Lublin 1992, Lubelskie Towarzystwo Naukowe.

[9] Iskrzycka I., Z dziejów Towarzystwa pod nazwa "Muzeum Lubelskie", studia i Materiały Lubelskie, 1968, vol. 8, p. 24, after: Lublinianin of 16.09.1907, no. 58.

[10] Kosmowska W., Domy ludowe u obcych i u nas, Warszawa; Lublin: Wydawnictwo M. Arcta, 1918 (Warszawa: Druk. M. Arcta). 
[11] Kosmowska W., Towarzystwo szkoły ludowej w Galicji z cyklu drogi do oświaty, Wydawnictwo M. Arcta w Warszawie, 1918.

[12] Kurcjusz A., Znaczenie Domów Ludowych w Polsce w dobie obecnej, Warszawa 1927.

[13] Łoza S., Architekci i budowniczowie w Polsce, Warszawa Budownictwo i Architektura, 1954.

[14] Natęczów zdrojowisko i letnisko sezon 1928/1929, Wydawnictwo Komisji Zdrojowej w Nałęczowie.

[15] Posner S., Domy Ludowe w Belgii, Wydawnictwo Krytyka, Kraków, 1907.

[16] Przegaliński A., W kręgu Stanisława Śliwińskiego i nałęczowskiej oświaty rolniczej na przełomie XIX i XX wieku, Rocznik Lubelski 35, 2009.

[17] Sosiński W., Jak zakładać dom ludowy i prowadzić towarzystwo domu ludowego wskazówki organizacyjne, Centralny Związek Kółek Rolniczych, Komisja Domów Ludowych, Warszawa 1925.

[18] Tarka M., Dzieje Nałęczowa, Towarzystwo Przyjaciół Nałęczowa, Nałęczów 1989. 